\title{
A Novel Mannose-binding Tuber Lectin from Typhonium divaricatum (L.) Decne (family Araceae) with Antiviral Activity Against HSV-II and Anti-proliferative Effect on Human Cancer Cell Lines
}

\author{
Yongting Luo ${ }^{1}$, Xiaochao Xu', Jiwei Liu', Jian Li', Yisheng Sun ${ }^{1}$, Zhen Liu ${ }^{1}$, Jinzhi Liu', \\ Els Van Damme ${ }^{2}$, Jan Balzarini ${ }^{3}$ and Jinku Bao ${ }^{1, *}$ \\ ${ }^{1}$ College of Life Sciences, Sichuan University, Chengdu 610064, China \\ ${ }^{2}$ Department of Molecular Biotechnology, Ghent University, 9000 Gent, Belgium \\ ${ }^{3}$ Rega Institute for Medical Research, Katholieke University Leuven, Minderbroederstraat 10, B-3000 Leuven, Belgium
}

Received 23 August 2006, Accepted 18 December 2006

\begin{abstract}
A novel mannose-binding tuber lectin with in vitro antiproliferative activity towards human cancer cell lines and antiviral activity against HSV-II was isolated from fresh tubers of a traditional Chinese medicinal herb, Typhonium divaricatum (L.) Decne by a combined procedure involving extraction, ammonium sulfate precipitation, ion exchange chromatography on DEAE-SEPHAROSE, CM-SEPHAROSE and gel-filtration on sephacryl $\mathrm{S}-200$. The apparent molecular mass of the purified Typhonium divaricatum lectin (TDL) was $48 \mathrm{kDa}$. TDL exhibits hemagglutinating activity toward rabbit erythrocytes at $0.95 \mu \mathrm{g} / \mathrm{ml}$, and its activity could be strongly inhibited by mannan, ovomucoid, asialofetuin and thyroglobulin. TDL showed antiproliferative activity towards some well established human cancer cell lines, e.g. Pro-01 (56.7 \pm 6.8), Bre-04 (41.5 \pm 4.8), and Lu-04 (11.4 \pm 0.3$)$. The anti-HSV-II activity of TDL was elucidated by testing its HSV-II infection inhibitory activity in Vero cells with $\mathrm{TC}_{50}$ and $\mathrm{EC}_{50}$ of $5.176 \mathrm{mg} / \mathrm{ml}$ and $3.054 \mu \mathrm{g} / \mathrm{ml}$ respectively. The full-length cDNA sequence of TDL was $1145 \mathrm{bp}$ and contained an 813-bp open reading frame (ORF) encoding a 271 amino acid precursor of 29-kDa. Homology analysis showed that TDL had high homology with many other mannose-binding lectins. Secondary and three-dimensional structures analyses showed that TDL is heterotetramer and similar with lectins from mannose-binding lectin superfamily, especially those from family Araceae.
\end{abstract}

Keywords: Antiviral activity, Anti-proliferative activity, Molecular cloning, Purification and characterization, Sequence analysis, Typhonium divaricatum (L.) Decne lectin

\footnotetext{
*To whom correspondence should be addressed.

Tel: 86-28-85410672; Fax: 86-28-85417281

E-mail: jinkubao@sina.com, baojinku@yahoo.com.cn
}

\section{Introduction}

Lectins, possessing at least one non-catalytic domain, are capable of recognizing and binding to polysaccharides or glycoproteins expressed on cell surfaces (Goldstein et al., 1980). The interaction of lectins with certain carbohydrate is as specific as enzyme-substrate or antigen-antibody interactions. Nowadays they are being widely used in studies of biochemistry, cell biology, immunology, glycobiology and have widespread applications in biomedical researches (Sharon and Lis, 1989), being one of the major forces driving the progress of glycoscience. Accumulating evidence indicated that lectins can bind to varieties of Gram-positive/negative bacteria, yeasts, viruses, protozoa, plant cells and animal cells, detecting subtle differences in complex carbohydrate structures.

Owing to the fine specificity, most plant lectins have been employed for various applications including cancer therapy and virus research. Varieties of alterations in carbohydrate structure have been observed in cancer cells, including increased sialylation and branching of complex carbohydrates, or occasional emergence of some novel structures (Kaur et al., 2006). In this endeavor, lectins are excellent candidates in cancer research and therapy for their usefulness in recognition of the alterations in malignant cells, for reducing the cell tumorigenicity, and for prognosis of immune status of patient. Moreover, many plant lectins possess inhibitory activity towards the infection by herpes simplex, including Canavalia ensiformis agglutinin, Concanavalin A (ConA) (Okada and Kim, 1972), Soybean agglutinin (SBA), Wisteria floribunda agglutinin (WFA), Narcissus pseudonarcissus agglutinin (NPA), Bauhinia purpurea agglutinin (BPA) and Eranthis hyemalis agglutinins (EHA) (Marchetti et al., 1995) at concentrations below their cytotoxicity threshold, indicating excellent implication in anti-HSV research.

During the last decade, lectins with interesting properties 
have been isolated and characterized (Van Damme et al., 1998). Interestingly, most of these plant lectins belong to a single monocot mannose-binding superfamily as revealed by their molecular evolution, physiological roles, sequence homologies, and exclusive specificity for mannose or mannoside. However, unlike aforementioned agglutinins, lectins from family Araceae exhibit either very weak or no affinity to mono-, di- or oligosaccharides, whereas they bind with great avidity to glycans or glycoproteins (Van Damme et al., 1995a). Typhonium divaricatum (L.) Decne, belonging to the family Araceae, is a traditional Chinese medicine herb endowing with detumescence, anti-inflammation and antivirus bioactivities. In this article, we are now poised to present our investigation aiming to reveal the structure and biological activity of a novel mannose-binding monocot araceous lectin extracted from bulbs of this plant. The lectin was found to possess various in vitro anti-proliferative activities towards human cancer cell lines and potent antiviral response against HSV-II at low concentration far below the cytotoxicity threshold.

\section{Materials and Methods}

Chemicals and reagents. N-Bromosuccinimide (NBS), urea, guanidine- $\mathrm{HCl}$, bovine serum albumin (BSA), Acyclovir, dimethylsulfoxide (DMSO), isopropanol, 3-(4,5-dimethylthiazol-2yl)-2, 5-diphenyltetrazolium bromide (MTT), most monosaccharides, oligosaccharides, their derivatives, polysaccharides and glycoproteins were purchased from Sigma (St. Louis, USA). Standard molecular weight markers (gel-filtration and SDS-PAGE protein markers) and ampholine of $\mathrm{pH}$ range 3.0-10.0 were procured from Amersham Pharmacia (New Jersey, USA). PUC18-T vector, RNA Extraction Kit and $3^{\prime}$ and 5' RACE kit were purchased from Takara Biotechnology, Dalian, China. All the other reagents were of analytical grade.

Plant material. Tubers of Typhonium divaricatum (L.) Decne were collected from the campus of Sichuan University, Chengdu, China, during the month of August, and were instantly frozen in liquid nitrogen and stored at $-70^{\circ} \mathrm{C}$ before use.

Cell lines and virus. The various human cancer cell lines employed i.e., Pro-01 (prostate), Lu-04 (lung), Bre-04 (breast), HepG2 (liver) and Hela (cervix), were procured from Di'ao Group, Chengdu, China. Cell lines were maintained in RPMI 1640 medium with $10 \% \mathrm{FCS}, 10 \mathrm{U} / \mathrm{ml}$ penicillin and $100 \mu \mathrm{g} / \mathrm{ml}$ streptomycin at $37^{\circ} \mathrm{C}$, in humidified atmosphere $\left(90 \%\right.$ air and $\left.10 \% \mathrm{CO}_{2}\right)$ in $\mathrm{CO}_{2}$ incubator (Heraeus, Heracell). African green monkey kidney cells (Vero) and herpes simplex virus type 2 (HSV-II strain 333) were obtained from West China Medical School of Sichuan University. Vero cells, in which HSV-II was propagated, were grown in RPMI 1640 (Gibco) supplemented with 10\% fetal bovine serum (FBS, Gibco) and penicillin, streptomycin and fungizone $(100 \mathrm{U} / \mathrm{ml}, 100$ and $2.5 \mu \mathrm{g} / \mathrm{ml}$, respectively). The virus was stored at $-70^{\circ} \mathrm{C}$ until used.
Protein determination. Protein concentration was determined as described by Lowry et al. (1951) using crystalline bovine serum albumin (BSA) as standard.

Purification of Typhonium divaricatum Lectin. Fresh tubers of $T$. divaricatum $(100 \mathrm{~g})$ were homogenized in $0.15 \mathrm{M} \mathrm{NaCl}$ using a Waring blender and soaked overnight at $4^{\circ} \mathrm{C}$ before filtered through muslin cloth. The slurry was centrifuged at $9,000 \mathrm{~g}$ for $20 \mathrm{~min}$ and the supernatant was collected and precipitated with $80 \%$ saturation of ammonium sulfate. It was thereafter dissolved in $20 \mathrm{mM}$ Tris$\mathrm{HCl}$, pH 8.0 (buffer A). The dialysate was loaded on a DEAESEPHAROSE equilibrated with buffer $A$ and eluted with 0-0.5 M $\mathrm{NaCl}$ gradient. Active fractions were pooled and dialysed against $20 \mathrm{mM}$ acetate buffer, pH 4.3 (buffer B) before applied to a CMSEPHAROSE column. Then active fractions were concentrated to $3 \mathrm{mg} / \mathrm{ml}$ and loaded onto a Sephacryl S-200 column equilibrated with $20 \mathrm{mM}$, PBS, pH 7.0 (buffer C). The purified lectin, designated as TDL, was obtained by elution from the column with buffer $\mathrm{C}$, followed by dialysis against distilled water and then lyophilization.

Determination of molecular mass of TDL by gel-filtration and SDS-PAGE. The molecular mass of TDL was estimated by gelfiltration chromatograph on the same Sephacryl S-200 column as mentioned previously following the procedure of P. Andrews (1964). The column was calibrated with soybean trypsin inhibitor (30.2 kDa), bovine serum albumin $(68 \mathrm{kDa})$, ovalbumin $(45 \mathrm{kDa})$, chymotrypsinogen A (25 kDa) and cytochrome C (12.5 kDa). Gelfiltration purified lectin was subjected to sodium dodecyl sulphate polyacrylamide gel electrophoresis (SDS-PAGE), $\mathrm{pH} 8.3$, using 11\% $(\mathrm{w} / \mathrm{v})$ acrylamide slab gel for subunit molecular mass determination as described by Laemmli (1970).

Hemagglutinating activity assays. Hemagglutinating activity of TDL was assayed in 96-well microtiter $U$ plates according to the serial double dilution method using rabbit erythrocytes (Oda and Minami, 1986). Agglutinating activity of the lectin sample was expressed as units, namely the reciprocal of the highest dilution giving a positive result. The specific hemagglutinating activity was defined as unit/mg protein (Wang et al., 2000).

Carbohydrates-binding specificity. For hemagglutinating inhibition tests, serial two-fold dilutions of sugar samples were prepared in phosphate-buffered saline. All dilutions were mixed with $25 \mu \mathrm{l}$ of TDL with two units. The mixture was allowed to stand for $30 \mathrm{~min}$ at $20^{\circ} \mathrm{C}$ and mixed with an equal volume of $2 \%$ rabbit erythrocyte suspension. Sugars or their derivatives were tested at concentration of $200 \mathrm{mM}$ while polysaccharides and glycoproteins at concentration of $4 \mathrm{mg} / \mathrm{ml}$. The minimal inhibitory sugar concentration (MIC) of the final reaction mixture, which completely inhibited the lectin preparation, was calculated.

Effect of temperature, $\mathrm{pH}$ and denaturants. To determine the thermal stability, TDL was dissolved in phosphate-buffered saline (PBS, $0.15 \mathrm{M}, \mathrm{pH} 7.0$ ) at $50 \mathrm{mg} / \mathrm{L}$ and treated at $10-100^{\circ} \mathrm{C}$ in $10^{\circ} \mathrm{C}$ increments for $1 \mathrm{~h}$. The samples were then cooled down to room temperature immediately in ice water. 
The effect of $\mathrm{pH}$ on activity of TDL was performed by dissolving the lectin to $50 \mathrm{mg} / \mathrm{L}$ in a buffer of desired $\mathrm{pH}$ and tested at $4^{\circ} \mathrm{C}$. The erythrocytes suspension used for the hemagglutination assay was also prepared in the same buffer. The buffers used were as follows: acetate for $\mathrm{pH} 2.0,4.0$ and 4.9, phosphate for $\mathrm{pH} 5.6$ and 7.0, Tris- $\mathrm{HCl}$ for $\mathrm{pH} 8.6$, carbonate for $\mathrm{pH} 10.0$ and $\mathrm{KCl} / \mathrm{NaOH}$ for $\mathrm{pH} 12.0$ (all $100 \mathrm{mM}$ ).

The effect of two denaturing agents i.e., urea and guanidine- $\mathrm{HCl}$, at a concentration range of $0-8.0 \mathrm{M}$, was tested on lectin activity by incubating $2 \mathrm{ml}$ of each denaturant solution (prepared in $0.02 \mathrm{M}$ PBS buffer, pH 7.0) with equal volume of TDL at $4^{\circ} \mathrm{C}$.

\section{Anti-HSV II assay}

Virus titration (Cytopathogenic effect). Quadruplicate confluent monolayers in 96-well plates were overlaid with equal volume of serial appropriately diluted virus suspension. After $1 \mathrm{~h}$ of adsorption, the unabsorbed virus was washed by PBS and fresh culture medium was added to each well. The morphology of Vero cells was inspected for microscopically detectable alterations, i.e. loss of monolayer, rounding, shrinking of cells, granulation, and vacuolization in the cytoplasm. After $72 \mathrm{~h}$ of incubation at $37^{\circ} \mathrm{C}$ in a $5 \% \mathrm{CO}_{2}$ incubator, the value of $\mathrm{TCID}_{50}$ (tissue culture infection dose) was calculated (Monks et al., 1991).

Cytotoxicity assay. Quadruplicate confluent monolayers in 96-well plates were overlaid with $0.2 \mathrm{ml}$ of serial twofold test sample. After $72 \mathrm{~h}$ of incubation, $20 \mu \mathrm{l}$ of 3-(4,5-dimethylthiazol-2-yl)-2,5diphenyltetrazolium bromide (MTT, $5 \mathrm{mg} / \mathrm{ml}$ in PBS) was added to each well, and the monolayers were incubated for $4 \mathrm{~h}$ at $37^{\circ} \mathrm{C}$. The resulting formazan precipitate was dissolved in isopropanol with the addition of DMSO and the extinctions were determined by absorbance $\left(\mathrm{OD}_{570-630}\right)$. $\mathrm{TC}_{50}$ (toxic concentration) was the concentration required to reduce the absorbance (OD) by 50\% (Kodama et al., 1996).

Antiviral assay. The antiviral activity of TDL against HSV-II was also assessed using MTT method (Kodama et al., 1996). In short, quadruplicate confluent monolayers in 96-well plates were preincubated with $20 \mu \mathrm{l}$ of 100 times diluted virus suspension $\left(10^{4}\right.$ $\mathrm{TCID}_{50} / \mathrm{ml}$ ) for $1 \mathrm{~h}$ at $37^{\circ} \mathrm{C}$. Then $0.2 \mathrm{ml}$ of maintenance medium containing appropriate serially diluted concentrations of the test sample was added. Acyclovir was used as the positive control for HSV-II. Cell control and virus control were run simultaneously. After 3 days of incubation, the absorbance $\mathrm{OD}_{530-630}$ was determined by Anthos Microplate Reader. The percentage of viable treated cells was calculated in relation to untreated controls and was defined as $50 \%$ effective concentration $\left(\mathrm{EC}_{50}\right)$. The therapeutic index (TI) was calculated from the ratio $\mathrm{TC}_{50} / \mathrm{EC}_{50}$ (Kodama et al., 1996).

Assay of in vitro anti-proliferative potential on human cancer cell lines. The in vitro anticancer potential of TDL against five human cancer cell lines including Pro-01 (prostate), Lu-04 (lung), Bre-04 (breast), HepG2 (liver) and Hela (cervix), was tested according to the method of Monks et al. (1991), known as SRB assay. Cells were seeded at $10^{4}$ cells/well in $100 \mu \mathrm{l}$ RPMI medium containing $10 \%$ FCS in 96-well tissue culture plate. These cell lines were suspended as single cells in the above-mentioned medium and incubated for $24 \mathrm{~h}$ in $\mathrm{CO}_{2}$ incubator. Subsequently, $100 \mu \mathrm{l}$ of lectin solution (prepared in RPMI 1640 medium) at concentrations ranging from $0-100 \mu \mathrm{g} / \mathrm{ml}$, was added to cells and incubated for $48 \mathrm{~h}$. After the incubation period, adherent cell cultures were mixed in situ by adding $50 \mu \mathrm{l}$ of $50 \%$ (v/v) trichloroacetic acid and incubated for $1 \mathrm{~h}$ at $4^{\circ} \mathrm{C}$. The supernatant was discarded and plates were washed five times with deionized water and dried. $50 \mu \mathrm{l}$ sulforhodamine B (SRB, $0.4 \% \mathrm{w} / \mathrm{v}$ in acetic acid) was added to each well and the cultures were incubated for $15 \mathrm{~min}$ at $4^{\circ} \mathrm{C}$. The unbound SRB was removed by washing with $1 \%$ acetic acid and plates were air-dried. The dye bound to basic amino acids of the cell membrane was solubilized with $200 \mu \mathrm{l}$ Tris buffer $(10 \mathrm{mM}$, pH 10.5 ) and the absorbance was measured at $540 \mathrm{~nm}$ using ELISA reader to determine the relative cell growth viability in the treated and untreated cells.

RNA extraction and full-length cDNA cloning. Total RNA was extracted from $T$. divaricatum bulbs using an RNA Extraction Kit (Takara Biotechnology, Dalian, China) and reversely transcribed with a cDNA synthesis primer AP (5'-GGCCACGCGTCGACTAG $\left.\operatorname{TAC}(\mathrm{T})_{21}-3^{\prime}\right)$. The 3 ' sequence of $T$. divaricatum lectin was obtained by rapid amplification of cDNA ends (RACE) with a 3'-full RACE kit (TaKaRa Biotechnology) with primer1 (5'-GACTGCAATCTG GTCTTGTACAA-3') and primer 2 (5'-GGCCACGCGTCGACTA GTAC-3'), designed according to the conserved mannose-binding amino acid sequence QDNVY present in conservative mannosebinding sites of mannose-binding lectins. PCR was performed under the following conditions: cDNA was denatured at $94^{\circ} \mathrm{C}$ for $30 \mathrm{~s}$, followed by 30 cycles of amplification $\left(94^{\circ} \mathrm{C}\right.$ for $30 \mathrm{~s}, 55^{\circ} \mathrm{C}$ for $30 \mathrm{~s}$ and $72^{\circ} \mathrm{C}$ for $2 \mathrm{~min}$ ) and $7 \mathrm{~min}$ at $72^{\circ} \mathrm{C}$. Specific primers $5^{\prime}-$ ACTTCGCATTCACCTTCTCCG-3' (primer 3), 5'-ATCATCATCT CCTCTGCAGCG-3' (primer 4), and 5'-CTTCGAGCCGGTCGAA AAGATG-3' (primer 5) were designed to amplify the 5' end of TDL. The RNA was reverse transcribed followed by tailing cDNA with primer 3 . The first round of PCR was performed with primer 4 and Abridged Anchor Primer (AAP). PCR was carried out as previous steps. The PCR product was diluted 50-fold for the third round of amplification with primer 5 and Abridged Universal Anchor Primer (AUAP). The PCR product was purified and cloned into a pUC18-T vector (Takara Biotechnology) for sequencing. Forward primer 6 (5'-ATGGCCTCCAAGCACCTCCTC-3') and reverse primer 7 (5'-TTACTTCGCATTCACCTTCTCC-3') were designed for the amplification of full-length cDNA of TDL. The thermal cycling program was the same as that utilized for $3^{\prime}$ and $5^{\prime}$ RACE.

Bioinformatic analysis of the sequence and structure of TDL. The DNA sequence and associated molecular information of TDL were analyzed using DNA Tools 6.0, Vector NTI 9.0 (invitrogen, Carlsdad, USA), HCAdraw 2 (Doriane, Paris, France) and SwissModel (http://swiss-model.expasy.org//SWISS-MODEL.html).

\section{Results and Discussion}

Purification of Typhonium divaricatum lectin. Preliminary experiments with crude extracts from tubers of Typhonium divaricatum (L.) Decne indicated the presence of a lectin that 
strongly agglutinated rabbit erythrocytes but was inactive with human erythrocytes irrespective of blood group. This was in agreement with other araceous lectins being all capable of agglutinating rabbit, guinea pig, rat and sheep erythrocytes but not human erythrocytes (Sandu et al., 1990). Thus erythrocytes from rabbit were employed for monitoring hemagglutinating activity during purification steps.

TDL was purified by a combination of ammonium sulphate fractionation, ion exchange and gel chromatography. After DEAE-SEPHAROSE and CM-SEPHAROSE chromatography, fraction $\mathrm{A}_{3}$ (Fig. 1A) and $\mathrm{B}_{2}$ (Fig. 1B) displayed highest activity after elution with $\mathrm{NaCl}$ linear gradient. Upon gel-filtration on Sephacryl S-200, the activity was observed on $\mathrm{C}_{2}$ which was fractionated from $\mathrm{B}_{2}$ (Fig. 1C). As shown in Table 1, the overall yield was approximately $1 \mathrm{mg} / \mathrm{g}$ fresh weight, corresponding to $12 \%$ of the total soluble tuber protein. This data, as well as the low purification fold, indicated high lectin content of the total extractable proteins present in storage tissues (Van Damme et al., 1995a). This is in consonance with earlier findings from family Araceae and compares with $1 \mathrm{mg} / \mathrm{g}$ in Arum maculatum bulbs (Allen et al., 1995), $3.2 \mathrm{mg} / \mathrm{g}$ in Arisaema flavum bulbs (Singh et al., 2004), $3.0 \mathrm{mg} / \mathrm{g}$ in Sauromatum venosum bulbs (Bains et al., 2005), and $1.1 \mathrm{mg} / \mathrm{g}$ in Arisaema helleborifolium Schott bulbs (Shangary et al., 1995).

Determination of molecular mass of TDL by gel-filtration and SDS-PAGE. Upon SDS-PAGE in the presence and absence of 2-mercaptoethanol, TDL migrated as an apparent single band of about $12 \mathrm{kDa}$ (Fig. 2), indicating the homogeneity of the lectin. Gel-filtration chromatography of the lectin gave a symmetrical single peak corresponding to an apparent molecular mass of $48 \mathrm{kDa}$ (Fig. 3). These results suggested the tetrameric nature of TDL in which subunits are not held by disulphide linkages but joined together by noncovalent bonds. This finding is in good agreement with most of araceous lectins which have no disulphide linkage between subunits (Anthony et al., 1995; Shangary et al., 1995; Singh et al., 2004; Singh et al., 2005).

Hemagglutinating activity and carbohydrates-binding specificity. Hemagglutinating test showed strong interaction ability of the lectin, for TDL maintained its activity even at concentration of $0.95 \mu \mathrm{g} / \mathrm{ml}$. The inhibitory concentrations of sugars and glycoproteins are given in Table 2. Unlike most lectins from other families, TDL differs distinctly in carbohydrate binding specificity, in that it readily formed precipitins with complex saccharides and various glycoproteins, such as mannan (yeast mannan extracted from Saccharomyces cerevisiae), asialofetuin, ovomucoid and thyroglobulin in a concentration-dependent manner, while other saccharides tested were devoid of any inhibitory effect at all. This observation was quite similar with other araceous lectins, including those from A. maculatum, C. esculenta and Xanthosoma sagittifolium, which were also precipitated by both asialoglycoproteins and yeast mannan, partially
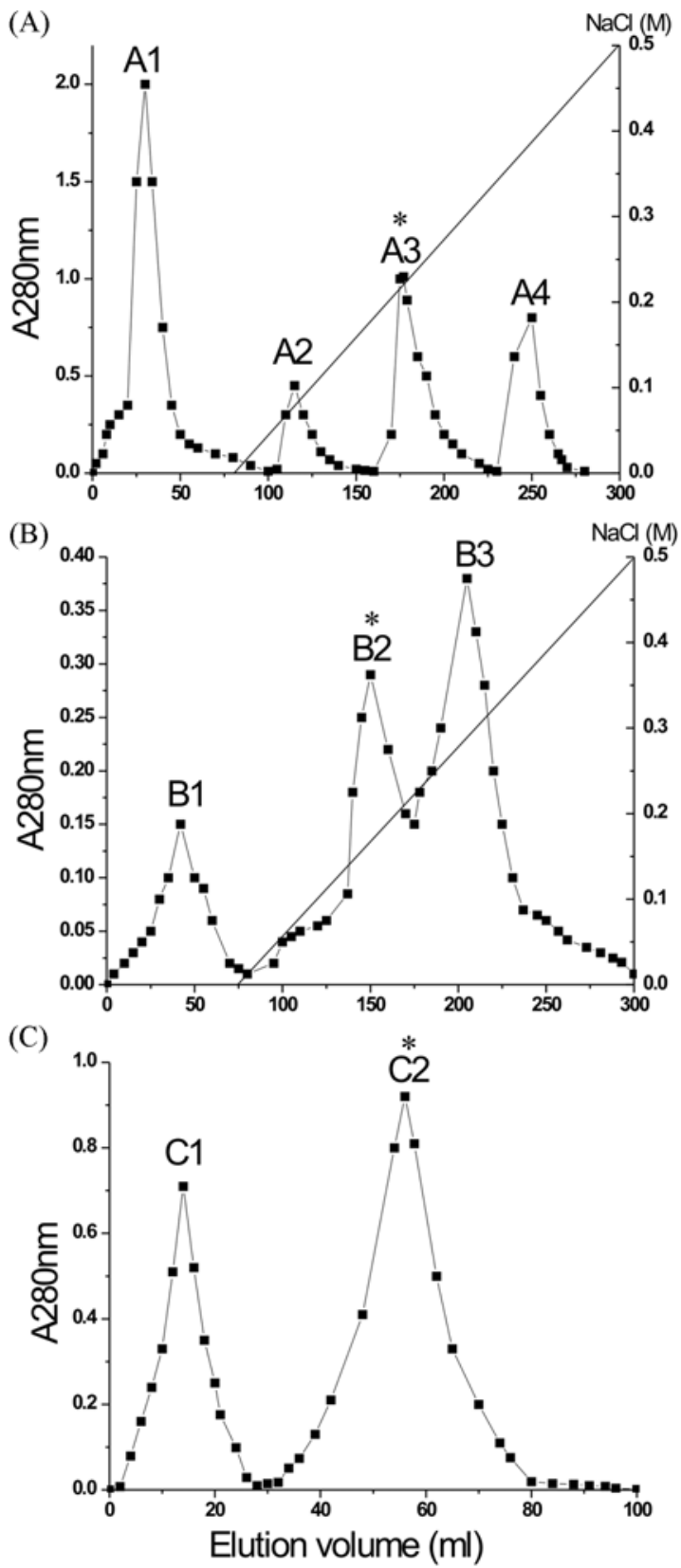

Fig. 1. (A) Anion exchange chromatography of proteins derived from the ammonium sulfate precipitate of Typhonium divaricatum (L.) Decne tuber extracts on DEAE-SEPHAROSE column preequilibrated with buffer $\mathrm{A}(\mathrm{pH}$ 8.0). The bound protein was eluted with $0-0.5 \mathrm{mM} \mathrm{NaCl}$ gradient at a flow rate of $1 \mathrm{ml} / \mathrm{min}$. (B) Anion exchange chromatography of fraction $\mathrm{A}_{3}$ on $\mathrm{CM}$ SEPHAROSE column pre-equilibrated with buffer $\mathrm{B}$ ( $\mathrm{pH} 4.3$ ) and eluted with $0-0.5 \mathrm{mM} \mathrm{NaCl}$ gradient at a flow rate of $2 \mathrm{ml} /$ min. (C) Gel-filtration of fracion $\mathrm{B}_{2}$ on Sephacryl S-200 column pre-equilibrated with buffer $\mathrm{C}(\mathrm{pH} 7.0)$ at a flow rate of $45 \mathrm{ml} / \mathrm{h}$. The elution profiles were monitored at $280 \mathrm{~nm}$.

supporting the idea proposed by Mo et al. (1999) that the presence of two distinct types of binding sites might be a general characteristic of araceous lectins. Just like other 
Table 1. Hemagglutinating activities of Typhonium divaricatum (L.) Decne lectin chromatographic fractions against rabbit erythrocytes

\begin{tabular}{lccccc}
\hline \multicolumn{1}{c}{ Steps } & $\begin{array}{c}\text { Yield } \\
(\mathrm{mg})\end{array}$ & $\begin{array}{c}\text { Specific } \\
\text { hemagglutinating } \\
\text { activity (HU/mg) }\end{array}$ & $\begin{array}{c}\text { Total } \\
\text { hemagglutinating } \\
\text { activity (HU) }\end{array}$ & $\begin{array}{c}\text { Recovery of } \\
\text { activity (\%) }\end{array}$ & $\begin{array}{c}\text { Folds of } \\
\text { purification }\end{array}$ \\
\hline $\begin{array}{l}\text { Crude extracts } \\
\text { DEAE-SEPHAROSE }\end{array}$ & 830 & 24 & 19920 & 100 & 1 \\
$\begin{array}{l}\text { Chromatography } \\
\text { CM-SEPHAROSE }\end{array}$ & 275 & 64 & 17600 & 87.5 & 2.7 \\
$\begin{array}{l}\text { Chromatography } \\
\text { Gel-chromatography }\end{array}$ & 141 & 99 & 14000 & 70.0 & 4.1 \\
\hline
\end{tabular}

The calculations represent the data for $100 \mathrm{~g}$ of tubers.

${ }^{a}$ Total hemagglutinating units and two percent of rabbit erythrocytes were used for hemagglutinating activity.

${ }^{b}$ Calculated as inverse of the minimum concentration producing a positive reaction in the hemagglutination assay.

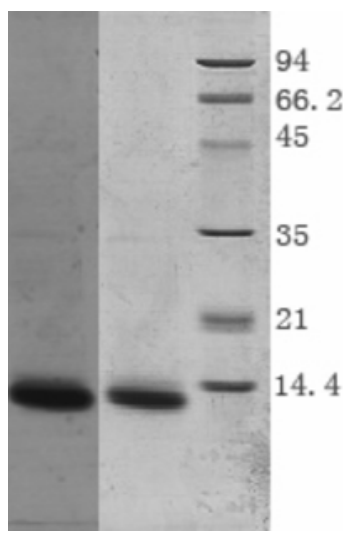

Fig. 2. SDS-PAGE, pH 8.3, patterns of purified TDL using $11 \%$ gel in the presence (lane left) and without (Lane in the middle) 2-mercaptoethanol (running time $3 \mathrm{~h}$ at a constant $100 \mathrm{~V}$ ). The amount of purified lectin loaded is $50 \mathrm{~g}$. Lane right, $\mathrm{Mr}$ markers (from top to bottom): Phosphorylase b ( $94 \mathrm{kDa})$; albumin bovine (66.2 kDa); ovalbumin (45 kDa); carbonic anhydrase (35 kDa); trypsin inhibitor $(21 \mathrm{kDa})$; and alactalbumin $(14.4 \mathrm{kDa})$. The gels were stained with Coomassie brilliant blue.

tetrameric lectins showing potent anti-tumor, insecticidal and antiviral properties, TDL might be of similar bioactivities due to the multi-valency and its capability to interact with great avidity towards complex glycol-conjugates.

Effect of temperature, $\mathbf{p H}$ and denaturants. When submitted to heat treatment, TDL is thermally stable over a wide range of temperatures from 20 to $60^{\circ} \mathrm{C}$. However, the activity starts to decline very rapidly afterwards, and is completely abolished after $10 \mathrm{~min}$ exposure at $90^{\circ} \mathrm{C}$ and $100^{\circ} \mathrm{C}$. TDL was quite stable from $\mathrm{pH} 5.6$ to 8.6 , and still retains $50 \%$ and $60 \%$ agglutination activity at $\mathrm{pH} 2$ and 12 respectively, suggesting the $\mathrm{pH}$ stability of the protein. Urea at $3.0 \mathrm{M}$ and guanidine$\mathrm{HCl}$ at $5.0 \mathrm{M}$ reduced the lectin activity by $50 \%$. The denaturation by these two agents indicates the globular nature of lectins, stabilized mainly by hydrophobic interactions (Kaur et al., 2006).

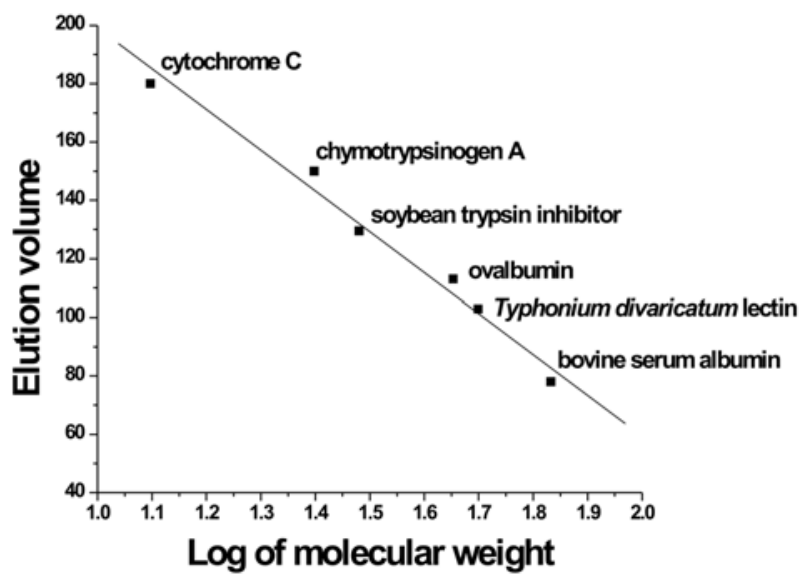

Fig. 3. Native molecular mass estimation by standard plot on gel-filtration chromatography column. Standards used for gelfiltration analysis were soybean trypsin inhibitor $(30.2 \mathrm{kDa})$, bovine serum albumin (68 kDa), ovalbumin $(45 \mathrm{kDa})$, chymotrypsinogen A $(25 \mathrm{kDa})$ and cytochrome C (12.5 kDa).

Anti HSV-II assay. The TCID T0 $_{5}$ of HSV-II against Vero cells, determined by cytopathogenic effect (CPE), was $10^{-4}$ in the virus titration assay. The amount of surviving cells after incubation with sample solutions at different concentrations was estimated by cytotoxicity assay. The toxicity of most formulations tested was relatively low and there were no significant differences between them (Table 3). The $\mathrm{TC}_{50}$ obtained was at $5.176 \mathrm{mg} / \mathrm{ml}$, indicating low cytotoxicity of the lectin towards Vero cells. As for antiviral assay, $43 \%$ and $60.4 \%$ inhibition was observed when the concentration of TDL was at $2 \mu \mathrm{g} / \mathrm{ml}$ and $4 \mu \mathrm{g} / \mathrm{ml}$ respectively for HSV-II, and $90.9 \%$ inhibition was observed at $8 \mu \mathrm{g} / \mathrm{ml}$ (Table 4 ). The $50 \%$ effective concentration $\left(\mathrm{EC}_{50}\right)$ obtained was comparatively low at $3.054 \mu \mathrm{g} / \mathrm{ml}$, and the therapeutic index (TI), calculated from the ratio $\mathrm{TC}_{50} / \mathrm{EC}_{50}$, was 1695 , suggesting excellent therapeutic security of the lectin. All these data pointed to the feasibility that TDL may be a good candidate for the treatment of human HSV-II and probably endowed with potential 
Table 2. Carbohydrate-binding specificity

\begin{tabular}{cc}
\hline Sugar/glycoprotein & $\begin{array}{c}\text { Minimum inhibitory sugar } \\
\text { concentration (MIC) in the } \\
\text { presence of TDL }\end{array}$ \\
\hline Mannan & $100 \mu \mathrm{g} / \mathrm{ml}$ \\
Asialofetuin & $75 \mu \mathrm{g} / \mathrm{ml}$ \\
Ovomucoid & $125 \mu \mathrm{g} / \mathrm{ml}$ \\
Thyroglobulin & $12.5 \mu \mathrm{g} / \mathrm{ml}$ \\
\hline
\end{tabular}

The carbohydrate-binding specificity was determined by hemagglutinating inhibition tests using a series of simple sugars and some glycoproteins. The following sugars were not inhibitory at a final concentration of $200 \mathrm{mM}$ : Sialic acid, Arabinose, N-acetylD-glucosamine, D-Mannose, 2-methyl-D-glucoside, N-acetygalactosamine, N-acetylactosamine, D-galactose, Maltose, D+ galactosamine, D-fructose, Lactose, D-Glucosamine Hydrochloride, Fetuin, Sucrose, Chitin, Sialofetuin. The Minimal inhibitory sugar concentration (MIC) required for complete inhibition was calculated and given bellow.

application in clinical therapy for this desease. Though the mechanism of the antiviral effect of the lectin was not clear at present, we extrapolate that TDL may bind the high-mannose glycans on the surface of the virus particles and directly interfered the binding of virus-cell membrane.

Assay of in vitro anti-proliferative potential on human cancer cell lines. The in vitro anti-proliferative activity of TDL was evaluated against five human cancer cell lines representing different organs and tissues namely Pro-01 (prostate), Lu-04 (lung), Bre-04 (breast), HepG2 (liver) and Hela (cervix). Table 5 shows the dose-dependent effect of
TDL with a concentration range of $0.01-100 \mu \mathrm{g} / \mathrm{ml}$, after a treatment period of 48 hours. Of the five cancer cell lines, TDL possesses the most deleterious effect towards Pro-01 $(56.7 \pm 6.8 \%)$, relatively milder toxicity towards Lu-04 $(41.5 \pm 4.8 \%)$, and only minor inhibitory towards Lu-04 $(11.4 \pm 0.3 \%)$, while the effect on the viability of HepG2 and Hela cell lines was undetectable. Some araceous lectins having potent anti-proliferative activities have also been reported earlier (Singh et al., 2004; Bains et al., 2005). However, the exact molecular mechanism of these action is poorly understood, but evidence is now emerging that lectins are dynamic contributors to tumor cell recognition, cell adhesion and localization, signal transduction across membranes, mitogenic stimulation, host immune defense augmentation, cytotoxicity and apoptosis (Karasaki et al., 2001). Saccharide determinants or glycoconjugates present on tumor cell surface serve as important binding sites for specific lectins. Differences in terminal sugars in various tumor cell lines can be one of the reasons for the variation of proliferation inhibition. TDL may interact with branches of complex carbohydrates located on the cell membrane of these cancer cell lines.

Full-length cDNA cloning of TDL. Based on the primers designed according to the conserved amino acid sequence of most monocot mannose-binding lectins, a 550-bp fragment of 3 ' end and a 800-bp fragment of 5' end of TDL cDNA were obtained. The full-length cDNA sequence of TDL, obtained using an RT-PCR reaction, was $1145 \mathrm{bp}$ and contained an 813-bp open reading frame (ORF) encoding a 271 amino acid protein (Fig. 4). The new nucleotide sequence data reported in the present study have been submitted to GenBank and are available under the accession number EF194099. According

Table 3. Cytotoxicity of TDL toward Vero cell line

\begin{tabular}{|c|c|c|c|c|c|c|c|c|c|c|}
\hline $\begin{array}{l}\text { Lectin concentration } \\
\qquad(\mathrm{mg} / \mathrm{ml})\end{array}$ & 8 & 4 & 2 & 1 & 0.5 & 0.25 & 0.125 & 0.0625 & control & $\begin{array}{c}\mathrm{TC}_{50}{ }^{a} \\
(\mathrm{mg} / \mathrm{ml})\end{array}$ \\
\hline OD & 0.438 & 1.182 & 1.213 & 1.249 & 1.335 & 1.434 & 1.479 & 1.499 & 1.520 & 5.176 \\
\hline$\pm \mathrm{S}^{b}$ & 0.02 & 0.01 & 0.04 & 0.03 & 0.01 & 0.04 & 0.02 & 0.02 & 0.02 & \\
\hline$\%$ inhibition $^{c}$ & 28.3 & 77.8 & 79.8 & 82.3 & 87.8 & 94.3 & 97.3 & 98.6 & & \\
\hline
\end{tabular}

${ }^{a} 50 \%$ cytotoxic concentration.

${ }^{b}$ Data represent mean values of OD for four independent experiments (mean value \pm S.D.).

${ }^{c}$ The percentage of inhibition was calculated in relation to untreated controls.

Table 4. Anti-HSV-II activity of TDL

\begin{tabular}{cccccccccc}
\hline $\begin{array}{c}\text { Lectin concentration } \\
(\mu \mathrm{g} / \mathrm{ml})\end{array}$ & 8 & 4 & 2 & 1 & 0.5 & 0.25 & $\begin{array}{c}\text { control } \\
\text { (virus) }\end{array}$ & $\begin{array}{c}\text { control } \\
(\text { cell })\end{array}$ & $\begin{array}{c}\mathrm{EC}_{50}{ }^{a} \\
(\mu \mathrm{g} / \mathrm{ml})\end{array}$ \\
\hline OD & 1.376 & 0.914 & 0.651 & 0.332 & 0.207 & 0.211 & 0.124 & 1.514 & 3.054 \\
$\pm \mathrm{s}^{b}$ & 0.27 & 0.18 & 0.23 & 0.14 & 0.11 & 0.13 & 0.07 & 0.03 & \\
$\%$ inhibition $^{c}$ & 90.9 & 60.4 & 43.0 & 21.9 & 13.7 & 13.9 & & & \\
\hline
\end{tabular}

${ }^{a} 50 \%$ cytotoxic concentration.

${ }^{b}$ Data represent mean values of OD for four independent experiments (mean value \pm S.D.).

${ }^{c}$ The percentage of viable treated cells was calculated in relation to untreated controls. 
Table 5. In vitro anti-proliferative effect of TDL

\begin{tabular}{cccccccc}
\hline & Human cell & \multicolumn{5}{c}{ Lectin dose $(\mu \mathrm{g} / \mathrm{ml})$} \\
\cline { 3 - 8 } & lines cancer & Control $(0)$ & 0.01 & 0.1 & 1.0 & 10 & 100 \\
\hline & Pro-01 & 0 & 0 & 0 & $9.2 \pm 0.4^{a}$ & $10.0 \pm 0.5$ & $56.7 \pm 6.8$ \\
Percentage of & Lu-04 & 0 & 0 & $0.2 \pm 0.1$ & $3.8 \pm 0.4$ & $7.4 \pm 0.5$ & $11.4 \pm 0.3$ \\
Inhibition (\%) & Bre-04 & 0 & 0 & $6.7 \pm 0.5$ & $8.4 \pm 1.3$ & $10.0 \pm 1.1$ & $41.5 \pm 4.8$ \\
& HepG2 & 0 & ND $^{b}$ & ND & ND & ND & ND \\
& Hela & 0 & ND & ND & ND & ND & ND \\
\hline
\end{tabular}

The anti-proliferative activity of TDL was tested on five human cancer cell lines: Pro-01, Lu-04, Bre-04, HepG2 and Hela. In the control wells, cells were cultured with medium alone (no lectins). The growth/inhibition of the cells was measured by ELISA reader.

${ }^{a}$ Data represent means \pm S.E.M. $(\mathrm{n}=3)$

${ }^{b}$ Effect undetectable.

to the rules of predicting lectin signal peptide (Von Heijine, 1986), a 24 amino acid signal peptide with the signal peptide cleavage site between $\mathrm{T}_{24}$ and $\mathrm{V}_{25}$ was identified from the fulllength cDNA sequence, which is in good agreement with

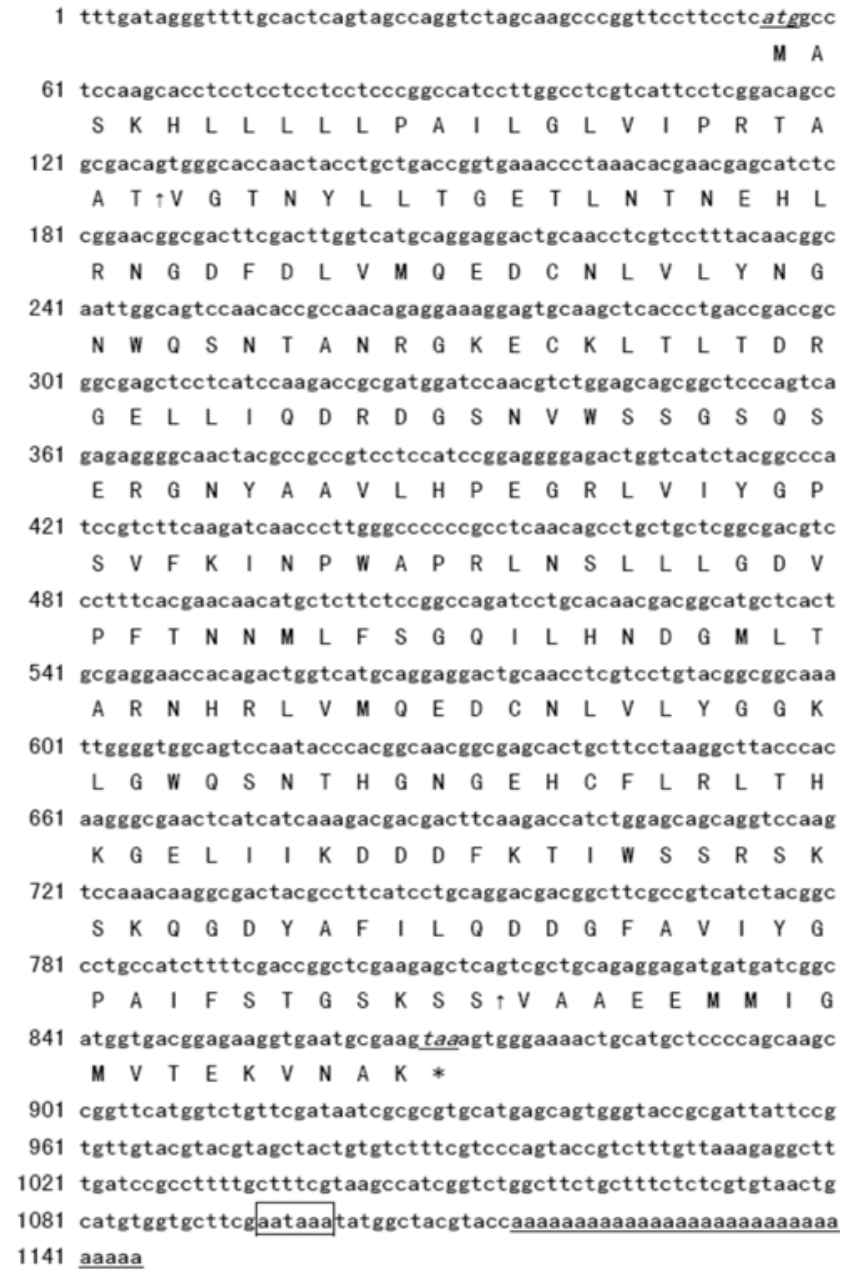

Fig. 4. cDNA sequence and deduced amino acid sequence of TDL. The start codon and the stop codon were underlined italically, the arrows indicate cleaving sites. The putative polyadenylation signal is boxed, and poly A was underlined. those of other Araceae species such as Colocasia esculenta (Hirai et al., 1993) and Arum maculatum (Van Damme et al., 1995a). The cleavage site of the C-terminal was between $S_{253}$ and $\mathrm{V}_{254}$. Translated with DNA Tools 6.0, the mature protein of TDL has two putative domians with a theoretic isoelectric point of 4.99 and 7.13, and a calculated molecular weight of $11.89 \mathrm{kD}$ and $12.09 \mathrm{kD}$ respectively. The richest amino acid residues were Leu (12.9\% by frequency), Gly (9.6\%), and Asn (7.7\%).

Homology analysis shows TDL has high homology with many other mannose-binding lectins. Database retrieval with PSI-Blast (National Center for Biotechnology Information databases) showed that TDL is a member of the monocot mannose-binding lectin superfamily. Homologous analysis showed that the identity between TDL and A. heterophyllum agglutinin, A. lobatum agglutinin, $P$. ternate agglutinin, $P$. pedatisecta agglutinin and $A$. maculatum agglutinin was 72.5 , $73.3,79.3,74.1$ and $66.1 \%$, respectively (Fig. 5). Recently, the molecular cloning of another lectin from Typhonium divaricatum (L.) Decne has been reported (Kong et al., 2006). The multialignment of Typhonium divaricatum agglutinin (TDA) and TDL sequences revealed only $21 \%$ homology between them (data not shown), indicating that they might be different lectins co-exist in the same plant.

Analysis of the secondary and three-dimensional structures of TDL. The analysis of secondary structure of TDL (Fig. 6) show that $\beta$-sheets, connected with turns and coils, occurred predominantly in the structure of TDL. The structural organization of $\beta$-sheets found in SCA (Wrigh et al., 1999) was generally conserved in TDL (data not shown) as revealed by hydrophobic cluster analysis (HCA) (Gaboriaud et al., 1987). Analysis ExPASy Molecular Biology Server (http://swiss-model.expasy.org) indicated that the overall structure of both domains (Fig. 7) are composed of three subdomains connected by pseudo-three-fold symmetry with each subdomain composed of a 4-stranded antiparallel $\beta$ sheet. The mannose-binding sites were located in the clefts formed by the three bundles of $\beta$-sheets. This was very similar 


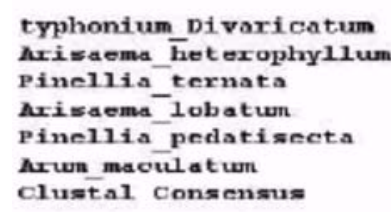

typhonium Divaricatum Axisaema_hetexophyllum Pincllia ternata Axisaema_lobatum Pinclia pedatisecta Arum maculatum Clustal Consensus

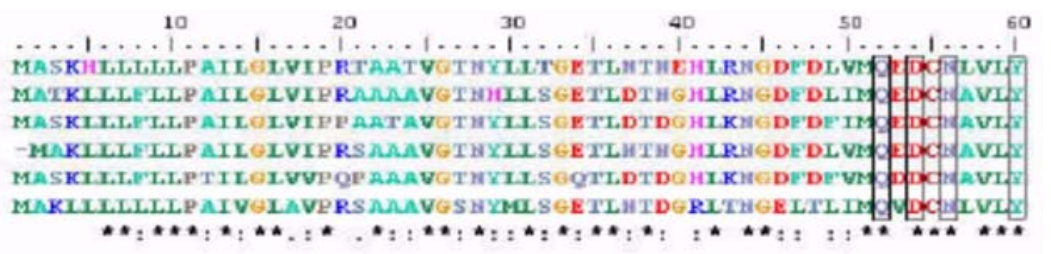

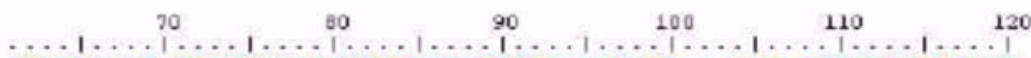

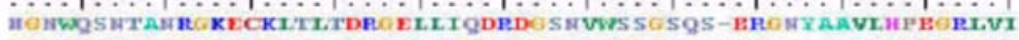

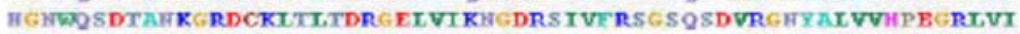

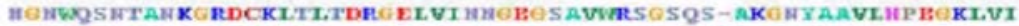

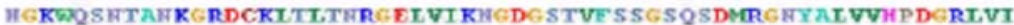
Н

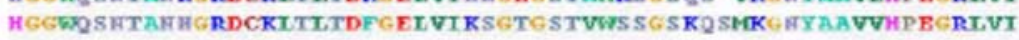

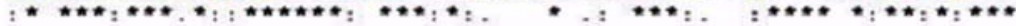

130

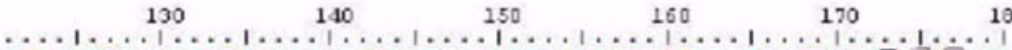

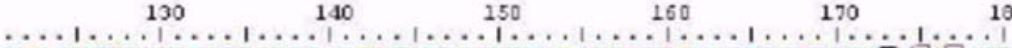

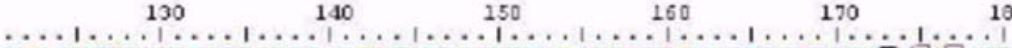

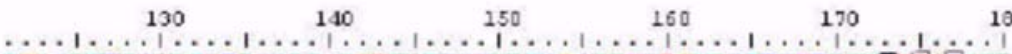
100

typhonium Divaxioatum Arigaema hetexophyllum Pinellia_ternata Arl saema_lobatum Pinellia pedatiseota Arum macul atum

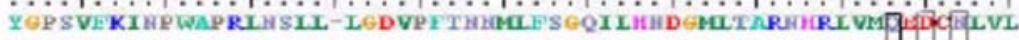

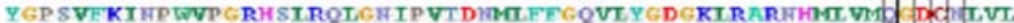

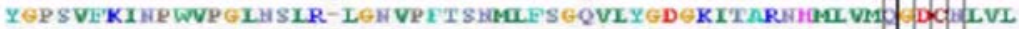

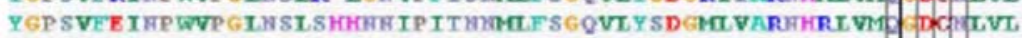

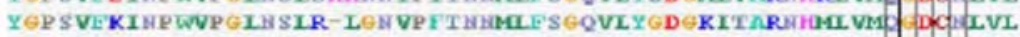

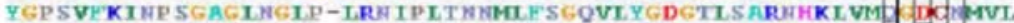

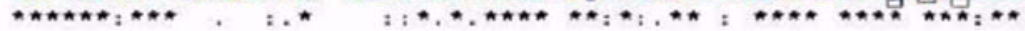
clustal consensus

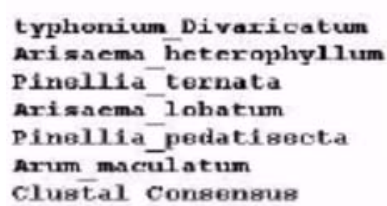

typhonium Divaxicatum Arisacma heterophyllum Pinellia ternata Axi $\approx a c m n$ - lobatum Pinellia pedatisecta Axum maculatum clustal Consensus

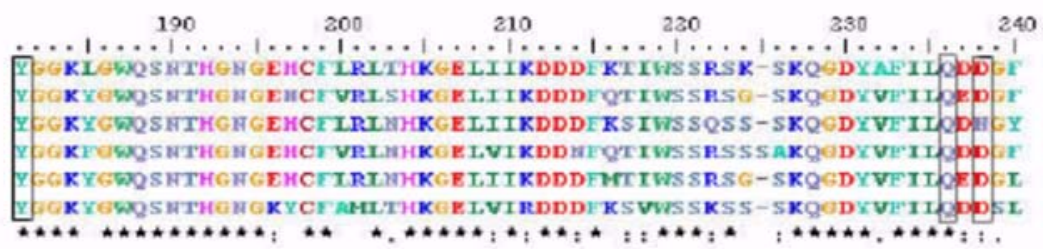

typhonium Divaxicatum Axisaema hetexophyllum Pincllia_ternata Axisaema_lobatum pinellia pedatisecta Arum maculatiun clustal Consensus

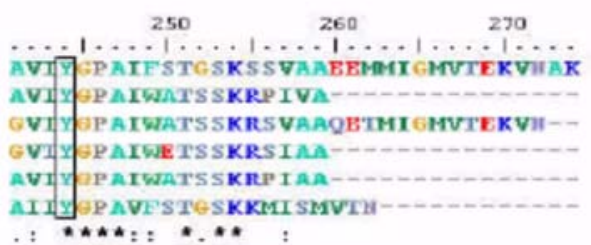

$\ldots 1 \ldots 1 \ldots 1 \ldots 1 \ldots 1 \ldots 1 \ldots$

AVI TPATFSTCSKSSVAAEEMMTCMUTEKVIIAK

QVIY TPA TYATS SKRSYAAOETMI MVTEKVI-

GVIX SPAYWETSSKRSIAA--

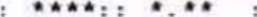

Fig. 5. Multi-alignment of the predicted $T$. divaricatum lectin (TDL) amino acid sequence with other monocot mannose-binding lectins from family Araceae. Arisaema lobatum (AY557617), Arisaema heterophyllum (AY338965), Pinellia ternata (AY451854), Pinellia pedatisecta (AY451853), Arum maculatum (AMU12198). The amino acid residues identical among any two of the six lectins were indicated with asterisk $(*)$. One amino acid residue different from those of the other five lectins were indicated with colon (:). Two amino acid residues different from those of the other four lectins were indicated with dot (.). Mannose-binding sites (QDNY) were boxed.

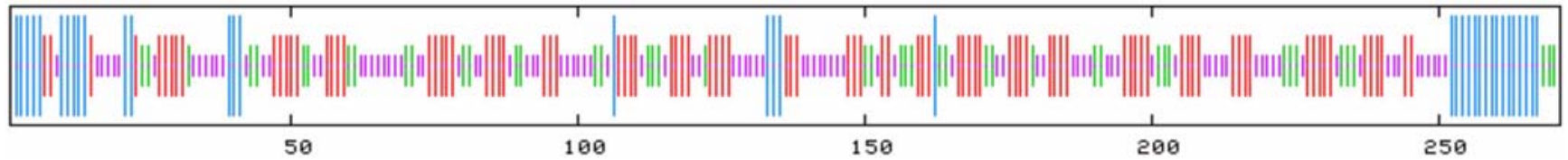

Fig. 6. The secondary structure of TDL. Helix, sheet, turn and coil were indicated, respectively, with cyan, red, green and purple vertical lines.

to the 3-D structure of many other mannose-binding lectins (Barre et al., 1996).

The database search indicated that the two putative conserved domains share $46.2 \%$ identity. Domain A was between $\mathrm{T}_{27}$ and $\mathrm{P}_{132}$ amino acid and domain $\mathrm{B}$ was between $\mathrm{N}_{146}$ and $\mathrm{S}_{253}$. Combined with the biochemical analysis showing TDL was a tetramer, it was deduced that TDL was first synthesized as a large precursor of $29-\mathrm{kDa}$ peptide that undergoes posttranslational removal of the 24-residue leader sequence the second cleavage near the center into two fragments. Thereafter, the proprotein undergoes further proteolytic modifications with the linker sequence and the 18-residue C-terminal peptide cleaved, resulting in two domains with nearly identical size, which finally assemble into the $(\mathrm{AB})_{2}$-heterotetramer 


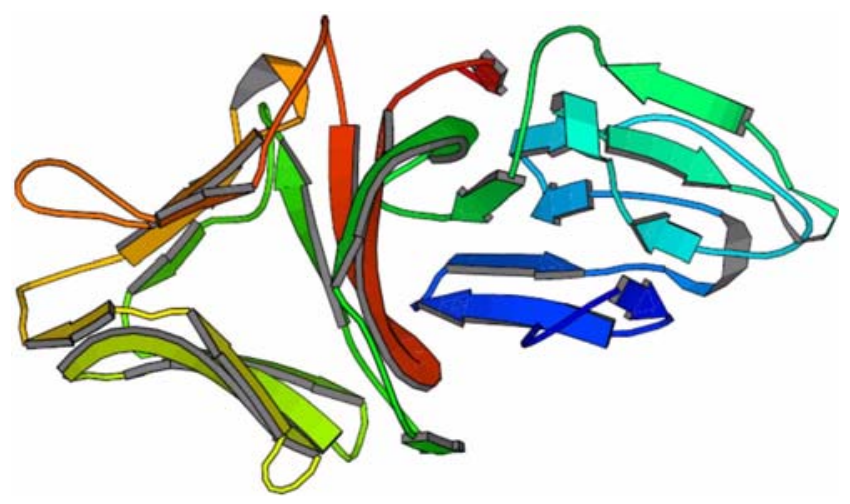

Fig. 7. The predicted tertiary structure of TDL. $\beta$--sheets were indicated by patches. Turns and loops were indicated by lines.

after the cleavage. This kind of post-translational process also occurs in other mannose-binding lectins, especially those from family Araceae (Van Damme et al., 1998), resulting in heterotetramers composed of four polypeptide chains, and each chain had similar size of 11-14 kDa (Van Damme et al., 1995b).

Only three of six subdomains of the two domains are made up of evolutionally conserved amino acid residues, mainly constituted by Gln (Q), Asp (D), Asn (N), Tyr (Y). Asn (N) was substituted by hydrophobic amino acid Phe (F) in the third mannose-binding pocket in TDL (Fig. 5). It should also be noted that there is a very good correlation between the number of active binding sites and the sugar-binding activity of mannose-binding lectins (Van Damme et al., 1998). The lack of interaction of TDL with simple sugars (i.e. mannose) may be due to the result of the replacement (deletion and insertion) of key amino acid residues within the monosaccharide-binding pockets during evolution. This kind of mutation results in the steric hindrances that prevent the binding of mannose into the active site through the network of hydrogen bonds. This mutation also occurs in many Araceous lectins such as AMA (Van Damme et al., 1995a) and CEA (Hirai et al., 1993). By the above comparison, it was found that TDL had many common characters possessed by mannose-binding lectins, especially those from Araceae.

This novel Araceous lectin, showing anti-proliferative activity towards various cancer cell lines and anti HSV-II effect of Vero cell line, may provide us with a rational basis for its efficiency in cancer and virus research and applications in modern clinical diagnosis of these diseases. Recently, TDL was found to have potent anti-insect activity against aphid by the experiment undertaking in our laboratory (data not shown). The purification, characterization and molecular cloning of TDL will enable us to study its potential insect resistance function in the future as well.

Acknowledgments This work was supported by grants from the National Natural Science Foundation of China (General Program No. 30000032 and 30270331) and Science and Technology Fund for Distinguished Young Scholars of Sichuan Province (No. 06ZQ026-035) and the Key Technologies R\&D Program of Sichuan Province (2006Z08-010). This work was also supported by the European Commission (EMPRO) and the Centers of Excellence of the K.U.Leuven (EF/05/15) (to JB). We gratefully acknowledge the contribution and enthusiasm of our coworkers and collaborators in our laboratories in the course of this investigation. We are also thankful to Dr Els Van Damme and Jan Balzarini for helpful comments and fruitful discussions.

\section{References}

Allen, A. K. (1995) Purification and characterization of an Nacetyllactosamine-specific lectin from tubers of Arum maculatum. Biochim. Biophys. Acta 1244, 129-132.

Andrews, P. (1964) Estimation of molecular weights of proteins by Sephadex gel-filtration. Biochem. J. 91, 222-233.

Bains, J. S., Singh, T. J., Kamboj, S. S., Nijjar, K. K., Agrewal, J. N., Kumar, V., Kumar, A. and Saxena, A. K. (2005) Mitogenic and anti-proliferative activity of a lectin from the tubers of Voodoo lily (Sauromatum venosum). Biochim. Biophys. Acta 1723, 163-174.

Barre, A., Van Damme, E. J. M., Peumans, W. J. and Rouge, P. (1996) Structure-function relationship of monocot mannosebinding lectins. Plant Physiol. 112, 1531-1540.

Gaboriaud, C., Bissery, V., Benchetrit, T. and Mornon, J. P. (1987) Hydrophobic cluster analysis: an efficient new way to compare and analyse amino acid sequences. FEBS Lett. 224, 149-155.

Goldstein, I. J., Hufhes, R. C., Monsigny, M., Osawa, T. and Sharon, N. (1980) What should be called a lectin? Nature $\mathbf{2 8 5}$, 66.

Hirai, M., Nakamura, K., Imai, T. and Sato, T. (1993) cDNAs encoding for storage proteins in the tubers of taro (Colocasia esculenta Schott ). Jpn. J. Genet. 68, 229-236.

Karasaki, Y., Tsukamoto, S., Mizusaki, K., Sugiura, T. and Gotoh, S. (2001) A garlic lectin exerted an antitumor activity and induced apoptosis in human tumor cells. Food Res. Int. 34, 713.

Kaur, M., Singh, K., Rup, P. J., Saxena, A.K., Khan, R. H. Mohd, T. A., Sukhdev Singh Kamboj, S. S. and Singh, J. (2006) A tuber lectin from Arisaema helleborifolium Schott with antiinsect activity against melon fruit fly, Bactrocera cucurbitae (Coquillett) and anti-cancer effect on human cancer cell lines. Arch. Biochem. Biophys. 445, 156-165.

Kodama, E., Shigeta, S., Suzuki, T. and De Clercq, E. (1996) Application of a gastric cancer cell line (MKN-28) for antiadenovirus screening using the MTT method. Antiviral Res. 31, 159-164.

Kong, W. W., Deng, Z. X., Fei, J., Wang, Q., Sun, X. F. and Tang, K. X. (2006) Characterization of a mannose-binding lectin gene from Typhonium divaricatum (L.) Decne. Afr. $J$. Biotechnol. 5, 793-799.

Laemmli, U. K. (1970) Cleavage of structural proteins during the assembly of the head of bacteriophage T4. Nature 227, 680685.

Lowry, O. H., Rosebrough, N. J., Farr, A. L. and Randall, R. J. (1951) Protein measurement with folin phenol reagent. J. Biol. 
Chem. 193, 265-275

Marchetti, M., Mastromarino, P., Rieti, S., Seganti, L. and Orsi, N. (1995) Inhibition of herpes simplex, rabies and rubella viruses by lectins with defferent specificities. Res. Virol. 146, 211-215.

Mo, H. Q., Rice, K. G., Evers, D. L., Winter, H. C., Peumans, W. J., Van Damme, E. J. M. and Goldstein, I. J. (1999) Xanthosoma sagittifolium tubers contain a lectin with two different types of carbohydrate-binding sites. J. Biol. Chem. 274, 33300-33305.

Monks, A., Scudiero, D., Skehan, P., Shoemaker, R., Paull, K., Vistica, D., Hose, C., Langley, J., Cronise, P. and Vaigro-Wolff, A. (1991) Feasibility of a high-flux anticancer drug screen using a diverse panel of cultured human tumor cell lines. J. Natl. Cancer Inst. 83, 757-766.

Oda Y. and Minami K. (1986), Isolation and characterization of a lectin from tulip bulbs, Tulipa gesneriana. Eur. J. Biochem. 159, 239-245.

Okada, Y. and Kim, J. (1972) Incubation of concanavalin A with enveloped viruses and host cells. Virology 50, 507-515.

Sandu, R. S., Arora, J. S., Chopra, S. K., Pelia, S. S., Kamboj, S. S., Naidu, Y. C. and Nath, I. (1990) Occurrence and isolation of new lectins of plants, fungi, and bacteria; in Lectins, Biology, Biochemistry, Clinical Biochemistry, Kocourek, J. and Freed, D. L. J. (eds.), pp. 19-33, Sigma Chem. Co., USA.

Shangary, S., Singh, J., Kamboj, S. S., Kamboj, K. K. and Sandhu, R. S. (1995) Purification and properties of four monocot lectins from the family araceae. Phytochemistry 40, 449-445.

Sharon, N. and Lis, H. (1989) Lectins as cell recognition molecules. Science 246, 227-234.

Singh, J., Singh, J. and Kamboj, S. S. (2004) A novel mitogenic and antiproliferative lectin from a wild cobra lily, Arisaema flavum. Biochem. Biophys. Res. Commun. 318, 1057-1065.

Van Damme, E. J. M., Goldstein, I. J., Vercammen, G., Vuylsteke, J. and Peumans, W. J. (1992) Lectins of members of the Amaryllidaceae are encoded by multigene families which show extensive homologies. Physiol. Plantarum. 86, 245-252.

Van Damme, E. J. M., Goossens, K., Smeets, K., Van Leuven, F., Verhaert, P. and Peumans, W. J. (1995a) The major tuber storage protein of araceae species is a lectin. Characterization and molecular cloning of the lectin from Arum maculatum. Plant Physiol. 107, 1147-1158.

Van Damme, E. J. M., Smeets, K. and Peumans, W. J. (1995b) The mannose binding monocot lectins and their genes; in: Lectins, BioMedical Perspectives, Pusztai, A. J., Bardocz, S. (eds.), pp. 59-80, Taylor and Francis Ltd, London, U.K.

Van Damme, E. J. M., Peumans, W. J., Barre, A. and Rouge, P. (1998) Plant lectins: A composite of several distinct families of structurally and evolutionary related proteins with diverse biological roles. Crit. Rev. Plant Sci. 17, 575-692.

Von Heijine, G. (1986) A new method for predicting signal sequence cleavage sites. Nucleic Acids Res. 14, 4683-4690.

Wang, H., Gao, J. and Ng, T. B. (2000) A new lectin with highly potent antihepatoma and antisarcoma activities from the oyster mushroom Pleurotus ostreatus. Biochem. Biophys. Res. Commun. 275, 810-816.

Wrigh, L. M., Reynolds, C. D., Rizkallah, P. J., Allen, A. K., Van Damme, E. J. M., Donovan, M. J. and Peumans, W. J. (1999) Structural characterisation of the native fetuin-binding protein Scilla campanulata agglutinin: a novel two-domain lectin. FEBS Lett. 468, 19-22. 